\title{
MANAGING ORGANIZATIONAL CHANGE IN COMMUNAL PUBLIC ENTERPRISES: A LITERATURE REVIEW
}

\author{
Georgi Hristov ${ }^{1}$, Gligorče Vrtanoski ${ }^{2}$ \\ ${ }^{1}$ MSc Student at the Faculty of Mechanical Engineering, "Ss. Cyril and Methodius" University in Skopje, \\ P.O. box 464, MK-1001, Skopje, Republic of North Macedonia \\ ${ }^{2}$ Faculty of Mechanical Engineering, "Ss. Cyril and Methodius" University in Skopje, \\ P.O. box 464, MK-1001, Skopje, Republic of North Macedonia \\ gligorche.vrtanoski@mf.edu.mk
}

\begin{abstract}
A b s t r a c t: This work presents a literature review regarding the organizational change. The resistance to change - a "natural associate" on change - was not considered as a separate topic under the scope of this work. More than thirty academic articles were reviewed and analyzed. An effort was done to link, to confront and, whenever possible, to compare the different findings about the organizational change as found by the academic research. In general, the review focuses on the organizational change literature and, in particular, the available peer reviewed academic articles that focus on the organizational change in public sector. The influence of different factors and behaviours (employees' participation and commitment, the change context, the management and leadership support, timing, communication and strategic change process) over the change process was examined. Some models for implementation the change process and the revolutionary change are mentioned. The concept of changing "whole system" is also mentioned as an important one when speaking about the change in public sector. The lack of research regarding the organizational change in communal public enterprises is noted and suggestions for further research are given.
\end{abstract}

Key words: change process; organizational change; communal public enterprise

\section{УПРАВУВАЊЕ СО ОРГАНИЗАЦИСКИТЕ ПРОМЕНИ ВО КОМУНАЛНИТЕ ПРЕТПРИЈАТИЈА: ПРЕГЛЕД НА ЛИТЕРАТУРАТА}

\begin{abstract}
А п с т р а к т: Трудот дава преглед на литературата во врска со организациските промени. Отпор кон промените, што природно го следи нивното воведување, не беше посебно анализиран. Анализирајќи над 30ина академски и научни трудови, беше направен обид да се поврзат, спротистават и, секогаш кога е можно, да се споредат различните научни сознанија за организациските промени. Општо земено, прегледот се фокусира на литературата за организациските промени со посебен акцент на научните трудови кои се однесуваат на јавниот сектор. Трудот го проучува влијанието на различните фактори (учеството на вработените и нивната посветеност, контекстот на промените, управувањето и поддршката од раководството, времето, комуникацијата и процесот на стратешки промени) во текот на процесот на промена. Споменати се некои модели за имплементација на процесот на промени и радикални промени се споменати. Концептот за промена на „целиот систем“ е спомнат како клучен во случај на промени во јавниот сектор. Нотиран е недоволниот број истражувања на организациските промени во комуналните јавни претпријатија се нотирани и се дадени предлози за понатамошни истражувања.
\end{abstract}

Клучни зборови: процес на промена; организациски промени; комунално јавно претпријатие

\section{INTRODUCTION}

Provision of potable water in the Republic of $\mathrm{N}$. Macedonia is responsibility of municipalities which establish utility companies named as Communal Public Enterprises (CPEs). The term "public" refers that the government (local or central) owns the utility and that the goods or services are provided in a 
monopolistic market. Since the collapse of communism in late 80 's, the planned economy has been replaced by market economy and most of stateowned companies have been privatized. However, the water utility companies are still operating, or better to say "surviving" as public enterprises. Decentralization process transferred many responsibilities for delivery of public services from central governmental level to municipalities, but it has not been followed with suficient funds to develop the sector adequately. Thus, the current situation at CPEs can be characterized as a critical one due to: poor operational and financial performance, long debt collection period, over employment, outdated IT and other equipment $[1,2]$. Additionally, even day-to-day operations seem to be highly influenced by political interests. In short, the current operations of the CPEs, still carrying much legacy of the former system, are not sustainable anymore and could harm and potentially destroy the water supply systems in operation. An intensive debate about different possible forms of CPEs' transformation, like privatization, concession, build-operate-transfer (BOT), public-private partnership (PPP), outsourcing, contracting etc., which might replace the existing (unsustainable) way of service delivery is ongoing. Whatever form is decided, and eventually applied, the changes are inevitable in the CPEs.

The publication "Introduction to Outsourcing and EU Water Sector Review" authored by the Association of Communal Service Providers (ADKOM) urged for an immediate action to improve (1) financial liquidity, (2) maintenance of the water supply networks and (3) capital investments [3]. Additionally, it showed that both, the politically appointed managers and employees agreed that "something" must be changed. Therefore, the municipalities face the challenges to find solutions for immediate improvement in the sector. Some have called for "radical" changes, too. In such a case, the universally accepted maxim that "people resist change" might not be true, at least verbally. This supportive environment toward change is in line with findings that individual resistance is quite rare [4]. Instead, it is suggested that obstacles to change more often reside in the organization's structure or in its performance appraisal or compensation system. This observation shifts the attention from individuals to the greater organizational system within which the change is occurring [5]. Also, the change outcomes are stronger when perceived need for change is high than when it is low [6], thus one can assume that current environment is supportive to introducing change process in communal public enterprisies.
Therefore, this article aims to provide literature review about the organizational change in the public utility sector. Eventually, it can serve the managers as a guide to the available academic findings on this topic to better prepare themselves, the enterprises and employees for a coming change process, but also to the asset owners as well as to customers.

Literature review of some academic research regarding the organizational change as found in the public enterprises is given in Section 2. It begins with some pioneering "classics" articles regarding the change and continues with the particular research and findings that address public enterprises. Section 3 gives short overview of Macedonian communal sector and assess possibilities for practical utilization of organizational change. Finally, the conclusion and recommendations for future research are given in Section 4.

\section{LITERATURE REVIEW}

\section{a) Organizational change}

Change is a part of life. In business context, particularly in recent years, as companies face increased competition, globalization, increased use of information and communication technologies, recession and at the same time search for excellence (or survival), changes are inevitably tied with the organizations [7]. Thus, managing change has attracted many researchers becoming a popular topic in the wider framework of social change [8] as well as in the organizational and management literature. Kurt Lewin - the "father" of the term resistance to change [9], - suggests a change-implementation process of unfreezing, moving (change) and refreezing. Relaying on Lewin's theory, Coch and Franch published the first known reference [10] on resistance to change concluding that groups which participate in the design and development of the changes have much lower resistance than those that do not. Furthermore, they advise managers to hold meetings, communicate the need for change and encourage employees' participation in change planning. Later, it has been noted that the Coch and Franch's research is actually about the participation, not about the resistance $[9,11]$.

Recently, many authors [12, 6] recommend employees' participation as a strong tool for successful change process. But, others have challenged this finding as well. For instance, even long ago [11], additional criticism of the Coch and French's 
study regarding the concept of participation has been expressed. In this sense, the Lawrence's study symbolizes a first effort to escape from dominant thinking that participation as a magic panacea for every change misfortune. Kotter and Schlensiger were among the first who claimed that organizations and individuals need to change continually [4]. Utilizing the contingency approach, they suggested that one must consider the context in which the changes occur as well. This is in line with findings suggesting that organizational change is difficult to separate from the context of the business it is in [13]. Therefore, it is essential to have a thorough understanding of the organization and its people, as well as of the change and its consequences. Refference [12] agrees that the analysis of the context with the choice of a contingent strategy, question the idea that participation and involvement are the recipe for any change process.

Similarly to Lewin, but for the level of an organization, [14] distinguishes three stages in the organizational change process - idea generation, adoption and implementation. It distinguished between organizations that promote and those that resist change. In addition, [15] indicated that organizational change usually engages changes at three levels: individual, structures and systems, and climate (interpersonal style). Therefore, an individual's response to change depends not only on her/his personal characteristics, but also on the type of organization, the existing climate and culture. In this line, the mechanistic organizations (strong hierarchical structure, well defined job descriptions, authority and power based on seniority and experience) are far worse at managing and coping with change than organic organizations (flat structure, flexible job descriptions, weaker authority and procedures) [12]. Other contribution how organization can support employees in case of revolutionary change and to assess whether actions taken depend on various contextual criteria, is presented in [7]. The authors found that when "behaviours that are supportive of revolutionary change are undertaken ... there can be a positive impact on critical outcome variables. Conversely, when behaviours perceived as non-supportive are undertaken ... there can be a decidedly negative impact on both the organization and the employee" (p.197).

Other important determinant which influences change is time. Many behavioural scholars, business executives and management gurus agree that timing is one of the most important elements in planning, delivering, implementing and managing change [12]. Intentionally or not, most of the changes are planned and implemented during crisis. Some authors [16] consider it to be THE crucial variable. Even more, others claim that individual reactions are subject to modifications over time [12].

Communication is other important determinant influencing the implementation of change. The research literature points that communication is positively related with an effective change process [17]. Reference [6] contributed to change theory by addressing the knowledge gap related to participation in strategic change. The findings suggest that, generally, the use of participation seems to be strongly related to successful implementation of strategic change, particularly in case when a company faces the "survival threat". Also, it was confirmed again that "employees' perceptions of the organization's need for change interact with the use of participation, making the participation-outcome links stronger when perceived need for change is high than when it is low" (p.210).

Refference [6] proposes a 12-step model for change implementation. The model is based on three previous well-known change models, i.e. Kotter's 8-step model [18], Jick's 10-step model [19] and 7-step change acceleration process used at General Electric which follows notion of unfreezing, moving and refreezing [9]. While Kotter points out that "skipping any step creates only an illusion of speed with the consequence of no satisfying results" [18], in addition, it has been suggested that all 12 steps are not to be regarded only sequentially, but also as an integrated, iterative process to enable change [20]. But, do these criteria of strictly following the steps in a change process allow for flexibility regarding the organizational context? No, they do not. The reference [21] advises that any organizational context requires different change strategies and tools. Even more, they argue that if various change initiatives are not priority on top management agenda, if leadership is not seen as a vital component to successful implementation of change initiatives, then it is hard to accept that such an organization has committed itself to organizational change regardless of the model it has chosen.

Although it is generally accepted that employee commitment plays prominent role in the implementation change models, only recently a model on commitment to organizational change initiatives that could serve as guide towards systematic future investigation has been developed [22]. The model suggests that commitment could take different forms and have different implications on the nature 
and level of employees' behavioural support for a change. The further research [23] replicates and extends this model using samples from different change contexts. The fact that the obtained results are similar, provides for a proven evidence about generalization of the model proposed at [22]. In addition, refference [23] extended the previous findings by examining relations between commitment and behavioural support for change (1) over time and (2) in a non-western societal culture. Actually, the findings obtained with a sample of Indian managers were very similar to those obtained in [22] with Canadian nurses. Finally, the findings regarding the relations between commitment and support for organizational change are consistent with the claim that employee commitment is a key to the successful implementation of organizational change, but even more, they conclude that commitment to change is more important than commitment to the organization.

\section{b) Organizational change in public utilities}

The changes in public sector in most Western economies have been mainly inspired by increased demand for greater financial accountability, efficiency and effectiveness [24]. Others have found different reasons for initiating changes. For example, the reasons for initiating changes in public sector is to exhibit many features of the private sector, including some scope for entrepreneurial behaviour [25]. Reffernce [26] connects it with the need to deal with turbulent environments and shifting public sector towards greater competition by applying privatesector management style in public domain. Some public organizations used the Lewin's three-step model while others have adopted business process re-engineering [27]. Some authors argue that whatever model is implemented, the progress can be achieved only if a transformation team is appointed which has been given authority for change and internal power [28].

Many authors (e.g. [26 - 28]) agree about deep differences between public sector organizations and private companies when it comes to implementation of the organizational change. Some argue that governments have no alternative, but to utilize different market-based business-oriented reform in the public sector [29]. Contrary, others [30] argue that transferring change concepts and approaches from private to public sector can lead to contradictory results. From current perspective, the later findings seem to be the correct ones. This means that the concepts and approaches to organizational change in public sector should be accommodated to public context, which not necessarily has the same motive to introduce and implement change as private sector. This is supported by other authors [31] about what a "changed" public organization is expected to perform: enact new relationships and partnerships; think and act strategically; network with other agencies; manage resources effectively; redefine boundaries of systems and govern for accountability and transparency. In short, this type of change is different from other forms of organizational change as it involves the "whole system" approach - getting the widest representation in the room and that all stakeholders would try to improve the "whole system" at the same time [31].

\section{ORGANIZATIONAL CHANGE IN MACEDONIAN'S CPES}

Public enterprise is a form of government in business. It is expected to achieve economic and operational efficiency, and at the same time serve social or policy objectives and be accountable to the public. The reality in Republic of North Macedonia is that CPEs' assets are significantly depreciated and, in general, employees are old, poorly educated and not-motivated. Although over employment is evident, there are still pressures for additional new politically motivated employments. In addition, besides the awareness of need for change (and survive), there is an emphasized resistance to change due to fear of losing jobs, IT frustration, loosing political influence etc. As previously mentioned, there is on-going debate in the country about the urgent necessity of transforming (changing) the CPEs. The debate is mainly focused about what changes are to be implemented which will provide for companies' sustainability, improved service level delivery and increased customer satisfaction leading to increased performance and cheaper services eventually. The proposals fall in a continuum from full privatization, at one side, to keeping the public form, at the other side.

Practical examples of different management forms already exist over the world. For example, in Canada, water and sewage utilities are publicly owned and operated. In France, many municipalities contract out water and sewage operations to private companies. England and Wales have fully privatized their water and sewage services. Anyway, the main goal to be achieved is affording an efficient company that will provide quality service delivery at reasonable prices. Regarding the efficiency, some 
authors claim that there are several reasons to believe that public enterprises will be less efficient that private enterprises producing the same product [32]. They mainly relay on the studies reviewed [33] which offer quite convincing evidence that private firms are more efficient than public enterprises, even in different country settings and industries. For example, for water utilities, it was found that private firms are more efficient than public firms by amounts ranging from $15 \%$ to $40 \%$. Very contrary to these findings, others argue against privatization of CPEs as a possible change model for increasing efficiency [34]. They claim that CPEs appear no less efficient than privatized ones. Some of their arguments against are "that privatization carries significant risks in water and sanitation, given the nature of the service as a natural monopoly, the de facto lack of competition on an international scale, the difficulty of regulating multinational companies, especially in transition and developing countries, the potentially high economic and social costs of monopolistic behaviour by commercial operators" [34, p. 52]. Even more, they provide evidence that public water supply sector in transition and developing countries is as affordable as the developed countries.

A snapshot on the current efficiency of the already privatized Macedonian companies in other sectors is in line with above Lobina and Hall's findings. Namely, the evidence showed that the efficiency of the privatized companies has not increased as expected, although, the profitability does. The increased profitability satisfies an owner's interest only, however, on the costs of lower investments and capacity development. Very probably, weak regulatory and institutional mechanisms to control financial operations of private companies and lacking expertise in regulating public (particularly water supply services), might be enough arguments towards keeping public form of communal services delivery. However, this shall not prevent introducing change processes in the public enterprises' operations. It is only suggested that privatization might not be the magic panacea for solving the operation and financial inefficiency of public communal enterprises in Republic of North Macedonia.

Clearly, changes are necessary and urgent. The employees and management of Macedonian public companies are convinced in the need of change and, at least, verbally are supportive. However, the rumours against the change are already spread around. The issue of rumours is not a new one and it is already well addressed by organizational change and resistance to change literature. Three main reasons [35] are revealed for organizational resistance to change: technical barriers (habit and inertia), political reasons (threats to coalitions may signal leadership problems), and cultural reasons (lack of a climate's support of change, regressing to "old days" of operations). All three reasons perfectly fit in the current real situation with the political and cultural ones having probably the biggest influence in the Republic of North Macedonia. It is also important to note that the CPEs carry a huge legacy system and company's history of "status quo" and such enterprises which have not practiced changes before cannot carry out the change successfully [12].

\section{CONCLUSION}

The paper provided some insights of the basic organizational change factors with focus on public sector. Based on the literature reviewed it is obvious that public sector faces more challenges than private with managing the organizational change process. Many water supply utilities from Central and Eastern Europe experience the process of transformation in the last twenty years, however, on the other side, there is still lack of research regarding the change in public enterprises (e.g. [34-21]). Therefore, it is suggested for more research on the topic in the sector in order to fill-in the existing gap between the accumulated knowledge and theory about organizational change, in general, and the CPE's change, in particular. It is also advised to test the existing findings regarding the participation, communication, commitment, management and leadership support, etc. in public utility sector in Central and Eastern Europe.

Such future research should focus on contextual factors within the public enterprises bearing on mind the legacy they carry as well as political influence. In this regard, attention must be paid on different cultural settings, company's history and the customers. This "whole system" approach should be verified under such settings, as customers are an important stakeholder in public sector operations. This will enable to reveal the reasons and factors preventing public companies to achieve the required improvements when introducing change process, something what is well noted in [21].

\section{REFERENCES}

[1] Ristovski, B.: Benchmarking Project in 28 Utilities in the Republic of Macedonia, Country Report, Ministry of Finance of RM, 2014. 
[2] Hristov, G.: Do service quality and efficiency of water / wastewater enterprises urge reforms? Case of Macedonian Communal Public Enterprises (CPEs), Master Thesis, University of Sheffield, UK, 2009.

[3] Vrteski, J.: Introduction to Outsourcing and EU water sector review, ADKOM publication, 2008.

[4] Kotter, J. P., Schlesinger, L. A.: Choosing Strategies for Change. Harvard Business Review, Vol. 57, Issue 2, pp. 106-114 (1979).

[5] Jansen, K. J.: The Emerging Dynamics of Change: Resistance, Readiness, and Momentum, Human Resource Planning, Vol. 23, Issue 2 (2000).

[6] Lines, R.: Influence of participation in strategic change: resistance, organizational commitment and change goal achievement, Journal of Change Management, Vol. 4, Issue 3, pp. 193-215 (2004).

[7] Szamozi, L., Duxbury, L.: Development of a measure to assess organizational change, Journal of Organizational Change Management, Vol. 15, No. 2, pp. 184-201 (2001).

[8] Lewin, K.: Frontiers in group dynamics, I: Concept, method and reality in social sciences; social equilibria and social change, Human Relations, Vol. 1, pp. 5-41 (1947).

[9] Dent, E., Goldberg, S.: Challenging Resistance to Change, Journal of Applied Behavioral Science, Vol. 35, No. 1, pp. 25-41 (1999).

[10] Coch, L., French, J. R. P. Jr.: Overcoming resistance to change, Human Relations, Vol. 1, No. 4, pp. 512-532 (1948).

[11] Lawrence, P. R.: How to deal with resistance to change, Harvard Business Review, Vol. 32, No. 3, pp. 49-57 (1954).

[12] Giangreco, A.: A review of the literature and the discussion of the six issues in the analysis of resistance to change, Luic Papers, No. 79, Seria Economia Aziendale, 2000.

[13] Stace, D. A.: Dominant ideologies, strategic change, and sustained performance, Human Relations, Vol. 49, No. 5, pp. 553-70 (1996).

[14] Shepard, H. A.: Innovation Resisting and Innovation Producing Organizations, Journal of Business, Vol. 40, Issue 4, pp. 470-477 (1967).

[15] Goodstein, L. D., Burke, D.: Creating Successful Organizational Change, Organizational Dynamics, Vol. 19, Issue 4, pp. 4-17 (1991).

[16] Brief, A. P.: Attitudes In and Around Organizations, New York, Sage Publications, 1998.

[17] Hall, G., Rosenthal, J., Wade, J.: How to make reengineering really work, Harvard Business Review, Vol. 71, No. 12, pp. 119-31 (1993).

[18] Kotter, J. P.: Leading Change: Why Transformation Efforts Fail, Harvard Business Review, Vol. 73, No. 2, pp. 59-67 (1995).

[19] Jick, T.: Implementing Change, Harvard Business School Press, 1991
[20] Mento, A., Jones, R., Dirndorfer, W.: A change management process: Grounded in both theory and practice, Journal of Change Management, Vol. 3, No. 1, pp. 45-59 (2002)

[21] Soltani, E., Lai, P-C., Shams, N.: Learning about the Practice of Change Management: The Case of Non-for-Profit Organisations, Kent Business School, 122, 2006.

[22] Herscovitch, L., Meyer, J. P.: Commitment to organizational change: Extension of a three-component model, Journal of Applied Psychology, Vol. 87, Issue 3, pp. 474487 (2002)

[23] Meyer, J. P., Allen, N. J.: A three-component concepttualization of organizational commitment, Human Resource Management Review, No. 1, pp. 61-89 (1991).

[24] Hopwood, A.: Accounting and the pursuit of efficiency, Governance and the Public Sector, Vol. 2005, pp. 278-298 (2005).

[25] Leadbetter, C.: The Rise of the Social Entrepreneur, Demos, London, 1997.

[26] Hood, C.: A public management for all seasons? Public Administration, Vol. 69, Issue 1, pp. 3-19 (1991).

[27] Harrington, B., McLoughlin, K., Riddell, D.: Business process reengineering in the public sector: A case study of the Contributions Agency, New Technology, Work and Employment, Vol. 13, No. 1, pp. 43-50 (1998).

[28] Schein, A.: How Can Organizations Learn Faster? The Challenge of Entering the Green Room, Sloan Management Review, pp. 85-92 (1993).

[29] Williams, I.: Competing for quality: competition in the supply of central government services, in: R. Lovell (Ed.) Managing Change in the Public Sector, pp. 216-227, 1994.

[30] Sminia, H., Van Nistelrooij, A.: Strategic management and organization development: Planned change in a public sector organization. Journal of Change Management, Vol. 6 , Issue 1, pp. 99-113 (2006).

[31] Lowdnes, V., Skelcher, C.: The Dynamics of Multi-Organisational Partnership: An Analysis of Changing Mode of Governance. Public Administration, Vol. 76, Issue 2, pp. 313-333 (1998).

[32] Bradburd, R.: Privatization of Natural Monopoly Public Enterprises: The Regulation Issue, Review of Industrial Organization, Vol. 10, Issue 3, pp. 247-267 (1995).

[33] Borcherding, T. E., Ponunerehne, W. W., Schneider, F.: Comparing the Efficiency of Private and Public Production: The Evidence from Five Countries, Public Production, pp. 127-156, 1982.

[34] Lobina, E., Hall, D.: Public Sector Alternatives to Water Supply and Sewerage Privatization: Case Studies. International Journal of Water Resources Development, Vol. 16, Issue 1, pp. 35-55 (2000).

[35] Tichy, N., Devanna, M.A.: The Transformational Leader, John Wiley \& Sons, Inc., New York, 1986, p. 306. 